\title{
Improving Nurse Productivity Through Professionalism Self-Concept
}

\author{
I Gede Juanamasta ${ }^{1}$, Kusnanto $^{1}$ and Slamet Riyadi Yuwono ${ }^{2}$ \\ ${ }^{1}$ Faculty of Nursing Universitas Airlangga, Kampus C Mulyorejo, Surabaya, Indonesia \\ ${ }^{2}$ Poltekkes Kemenkes Surabaya, Surabaya,Indonesia
}

Keywords: Professional Self Concept, Productivity, Literature Review.

\begin{abstract}
Nurses are the biggest proportion of hospital staff. Nurses interact directly with patients in the services. Therefore, it directly affects quality of patient care and satisfaction as well as productivity and improvement of the hospital's image. Nurses believe that they have primary responsibility in the care and welfare of their patients. Some problem of nurses in the self-concept is the lack of communication nurses with the public and the invisible nurses in the media. The nurse's negative self-concept is partly due to the nurse himself. The positive self-concept of professional nurses can improve nurse self-confidence in appropriate nursing interventions to improve patient health status thereby increasing hospital productivity.
\end{abstract}

\section{BACKGROUND}

Hospitals are healthcare institutions that provide full range of personal health services providing inpatient, outpatient and emergency care (UU No.44 / 2009). Hospitals in Indonesia have challenges in facing with MEA and community demands related to service quality. Increasing government bugdet priority in health sector expected to improve the productivity of the hospital and the quality of service.

Data of several hospitals in Indonesia, related efficiency of service quality still not meet the standard of Indonesia Health Ministry (2007). RSUD Raden Mattaher Jambi (2013) patient satisfaction evaluation of nursing service obtained results 72\%. Dr. M. Djamil Padang (2013), the incidence of patient fall $0.18 \%$ from Minimum Standard Service (SPM) set 0\%, patient satisfaction rate $79.28 \%$ of SPM 90\%. In addition, Fatas's (2017) study at Hidayah Boyolali Hospital found that patients were less satisfied with doctors and nurses responsiveness and the attitude of doctors and nurses in listening to patient complaints.

In complex care systems, the responsibility of nurses and other professions to meet the demands of quality healthcare services expectations of health care consumers. Nurses are the biggest proportion of hospital staff. Nurses interact directly with patients in the services. Therefore, it directly affects quality of patient care and satisfaction as well as productivity and improvement of the hospital's image. (KemenkesRI, 2017; Kim, 2011).

\section{METHODS}

The literature search conducted in some database such as Gale, the Cochrane Library, EBSCO, ProQuest and Plos ONE. There were 39 articles that fulfil the inclusion criteria Strategies ways in search journal are done by using the keywords nurse professional self-concept and nurse productivity. Time limitation was used in January 2001 to August 2017.

\section{RESULTS}

The concept of productivity defined as the relationship between output and input (Krugman, 1997). In addition, the Asia Productivity Organization (APO) define productivity is combined between efficiency which means doing things right with the effectiveness of doing the right thing (Roghanian et al., 2012). The productivity of nurses implicitly influences the productivity of current and future nursing work. One's productivity may change in the future because of education and training, the intensity of physical capital and other factors. One's productivity may decline in the future, for example 
if one's skills are not updated with the latest sciences or work less because of ill health or become unproductive if retired.

Letvak and Buck (2008) mentioned factors related to decreasing work productivity are age, number of years of work as RN, quality of care given, work stress, work injuries, and health problems. Conceptually, Kopelman (1986 in Nursalam 2016) mentions the factors that affect the productivity of nurses consists of organizational factors, work factors and individual factors and work environment.

Individual factors related to the knowledge, skills and abilities and psychological nurses have a positive correlation with nurse performance (Mudallal et al., 2017; Yaghoubi et al., 2013). Brun et al. (2003) revealed it is important to explore and fully understand the potential psychological factors of nurses. High demand for nursing services, coupled with a lack of support from co-workers and leaders, reduced autonomy, tense working relationships between nurses and doctors, lack of respect from their managers (Brun et al., 2003), shifting organizational structure, and poor working climate (Mrayyan and Al-Faouri, 2008).

Psychological nurses related self-concept professional nurses reflect workers' emotions and opinions about their own performance and feelings towards themselves. Cowin et al. (2006) mentions nurse self-concept is an important point nurses who affect the career and it is very dependent on the experience of nurses in their profession. In particular, nurses with self-concept

Nurse with high professional self-concept give influence to other nurses. This has the effect of improving self-image, self-esteem, and other nurse confidence. In contrast, low professional selfconcept reduce productivity (Chi and Yoo, 2001). Research Arthur et al. (1999) discloses nurse professional relationships with their patients build on sincerity and reverence. Nurses around the world have a lot in common in terms of caring. Nurses believe that they have primary responsibility in the care and welfare of their patients (DahlborgLyckhage and Pilhammar-Anderson, 2009; Fagerberg and Kihlgren, 2001). ten Hoeve et al. (2014) mentions the problem of nurses in the selfconcept is the lack of communication nurses in the public and moreover they doesn't appear to be significant role at hospital in the media. Negative self-concept is partly due to the himself (Donelan et al., 2008; Takase et al., 2006). This is also in line with the research Arumsari et al. (2016) mentions the nurse's barrier in communicating.
Public does not pay attention to the position of the nursing field and the lack of dignity of the nursing field is mostly nurse experience, which leads to a decrease in self-esteem resulting in low selfconcept (Valizadeh et al., 2016). This has a stereotypical effect on nurses. Nurses need to prevent the impact of stereotypes and improve professional self-concept. An overview of stereotypes affects the nurses use autonomy. Nurses have need of inner strength for increasing self concept (Takase et al., 2002; Tzeng, 2006). According to Kemmer and Silva (2007), nursing education create nurses' inability in public mediation for themselves. They just think to still perform well in health care and never fix this problem. The nurse's inability will continue. Nurses need to increase the range of roles and chances of basic and advanced nursing practice offered to give more visibility to the nursing role, so that the community can recognize the role of the nurse (Kalisch et al., 2007; Kemmer and Silva, 2007).

The self-concept of professional nurses can improve the patient's health status through appropriate interventions thus increasing the productivity of the hospital. Nurses practitioner have a significant role related to hospital productivity, that important to improve nursing care with sustainable transformation in their workplace (Nam and Park, 2002). Good hospital productivity has an effect on customer satisfaction, it also provides more value in the public's view of the hospital. Research conducted by Cowin et al. (2008) revealed that professional status has a strong relationship with nurse self concept. This is also supported by research conducted by Randle (2001) suggesting that organizational and cultural climate have a strong influence on professional self-concept.

\section{DISCUSSION}

\subsection{Theory of the Nurse Professional Self Concept}

Professional self-concept established by providing good quality care to patients who are in the process of efficient and energy resulting in patient satisfaction (Lee and Yang, 2015).

The concept of a professional self, an attitude that develops from a professional experience, evolved from self-concept (Arthur, 1992). Professional development from nursing students to professional nurses has produced themes important for the development of self-identity and self-concept 
(Evans, 2001; Godinez et al., 1999; Leathart, 1994; Whitehead, 2001). Student nurses believe in professionalism by three different themes (belonging, knowledge, and affirmation). Other research results show, answers to questions from patients and family members, and what they add to the meaning of nursing professionalism (Secrest et al., 2003). In addition, general nursing students of the nursing faculty, clinical preceptor, peers in the clinical environment, and family influence in professional development (Heath et al., 2001; Kelly, 1992).

O'Mara et al. (2006) study have found selfconcept capable of improving job satisfaction and nurse retention plans. The results construction analysis show self-concept shows strong relationship to job retention global and job satisfaction, and this is in construction in the retention analysis. This is a strategy for improving the self-concept of nurses. Kovner et al. (2006) note, salary justice is more important than retention. In this study, nurse feel better to stay in nursing with self-concept improvements of general nurses and professional status.

In the study of Cowin et al. (2008), this study reveals the potential interrelationships between selfconcept and job satisfaction, in the hope of being able to. Strong positive correlation between professional status and general self-concept of nurse (NSCQ). Changes that like to increase the professional status of nurses have mutual effect on nurse self-concept in general and happiness. Approach to increase the professional status of nurses in health care and communities with exceptional plans in nurse retention plans (Takase et al., 2006). In line of this study, finding by Takase et al. (2006) relates to self-image and performance and the retention to stay. Increasing capability and lore in nursing and professional nurse self-concept may be can keep experienced staff (Cowin, 2001).

Preparation in education to address gaps between academia and services, so that the expectations of health organizations can be met. A better understanding of nursing experience after graduate can enable staff of teaching staff and health workers to improve professional self-concept and improve nurse retention.

Over the years the media has been instrumental in building the image of nurses. The nursing organization needs to provide restrictions on media and imaging in the media so as to maintain the image of the nurse. In addition, an equivalent education program with other health teams for members of the nursing team may provide an opportunity for equal professional status. (Williams, 2001).

\subsection{Factors of Nurse Productivity}

Nayeri points out that the productivity of nurses depends on the "human resources" factor that acts as the main variable. These parameters have a direct or indirectly significant relationship with effectiveness and efficiency. Management and organizational factors play a role in shaping a culture of productivity. Management and leadership styles affect the productivity, effectiveness and quality of staff services. In addition, employment status, employment patterns, organizational methods, nurse confidence level and a fair payment system based on individual performance and effectiveness are also factors affecting productivity. The need for training to support staff is constantly changing and should continue to be done in order to improve organizational performance (Dehghan Nayeri et al., 2006).

Human characteristics, such as education, experience, skills, knowledge, and competence are predictors of work productivity and are all associated with improved clinical care among nurses (Dehghan Nayeri et al., 2006). Factors in the nurse such as fatigue and stress can have a negative impact on productivity. Minimizing the time spent on nonmaintenance activities is needed to reduce fatigue and save the required nursing resources (Dehghan Nayeri et al., 2006). Work security and financial wealth are other important factors found to be associated with productivity.

Another aspect of nurse involvement is long working hours. According to recent research, a longer shift has been found to contribute to accidents, illness, absenteeism and increased workrelated errors and ultimately lower productivity (Dehghan Nayeri et al., 2006).

The balance between work and life has a positive effect on productivity. This indicates that the productivity of the nurses is equally related to the nurse's dignity and respect. Dignity and respect for work are indications of a respectful environment. The nurse's experience of respect is linked to cooperation, recognition, independence, support, and justice (Dehghan Nayeri et al., 2006).

The performance of managers is a primary factor that facilitates or inhibits the productivity of nurses. Characteristics of managers that affect the productivity of care is to direct the nurse by being role models, using leadership styles appropriately, motivating the team, supporting the team by 
providing recognition and rewards, maintaining good relationships, and providing solutions to staff problems. (Dehghan Nayeri et al., 2006).

\section{CONCLUSION}

All aspects of the individual, social and cultural level for the organization, both in terms of subjective and objective, should be explored more deeply (Arthur and Randle, 2007). Therefore, there needs to be a model from organizational level to individual. Based on that, the researcher is concerned to conduct research of self-concept modeling of professional nurse to the work productivity of the nurse in the inpatient ward of the hospital.

\section{REFERENCES}

2009. Undang-Undang Republik Indonesia No. 44 Tahun 2009, Jakarta.

Arthur, D., 1992. Measuring the professional self-concept of nurses: a critical review. Joumal of Advanced Nursing, 17: 9.

Arthur, D. et al., 1999. Caring attributes, professional self concept and technological in ${ }^{-}$uences in a sample of Registered Nurses in eleven countries. International Journal of Nursing Studies, 36: 10.

Arthur, D. and Randle, J., 2007. The Professional SelfConcept of Nurses: A Review of The Literature From 1992-2006. Australian Journal of Advanced Nursing, 24(3): 15.

Arumsari, D.P., Emaliyawati, E. and Sriati, A., 2016. Hambatan Komunikasi Efektif Perawat Dengan Keluarga Pasien Dalam Perspektif Perawat. Jurnal Pendidikan Keperawatan Indonesia, 2(2): 11.

Brun, J.-P., Biron, C., Martel, J. and Ivers, H., 2003. Evaluation of Mental Health at Work: An Analysis of Human Resources Management Practices, Institut de recherche Robert-Sauvé.

Chi, S.A. and Yoo, H.S., 2001. Concept Analysis of Professional Nurse Autonomy. J Korean Acad Nurs, 31(5): 781-792.

Cowin, L., 2001. Measuring Nurses' Self-Concept. Western Journal of Nursing Research, 23(3): 13.

Cowin, L.S., Craven, R.G., Johnson, M. and Marsh, H.W., 2006. A longitudinal study of student and experienced nurses' self-concept. Collegian, 13(3): 7.

Cowin, L.S., Johnson, M., Craven, R.G. and Marsh, H.W., 2008. Causal modeling of self-concept, job satisfaction, and retention of nurses. Int J Nurs Stud, 45(10): 1449-59.

Dahlborg-Lyckhage, E. and Pilhammar-Anderson, E., 2009. Predominant discourses in Swedish nursing. Policy Polit Nurs Pract, 10(2): 163-71.
Dehghan Nayeri, n., Nazari, a.a., Selsali, m. and Ahmadi, f., 2006. Viewpoints of Nurses about Productivity and the Effects of Current Evaluation Process on it. scientific magazine yafte, 7(4): 91-100.

Donelan, K., Buerhaus, P., DesRoches, C., Dittus, R. and Dutwin, D., 2008. Public perceptions of nursing careers: the influence of the media and nursing shortages. Nurs Econ, 26(3): 143-50, 165.

Evans, K., 2001. Expectations of newly qualified nurses. Nursing Standard, 15(41): 33-38.

Fagerberg, I. and Kihlgren, M., 2001. Experiencing a nurse identity: the meaning of identity to Swedish registered nurses 2 years after graduation. J Adv Nurs, 34(1): 137-45.

Godinez, G., Schweiger, J., Gruver, J. and Ryan, P., 1999. Role transition from graduate to staff nurse: a qualitative analysis. Journal for Nurses in Professional Development, 15(3): 97-110.

Heath, J., Andrews, J. and Graham-Garcia, J., 2001 Assessment of professional development of critical care nurses: A descriptive study. American Journal of Critical Care, 10(1): 17.

Kalisch, B.J., Curley, M. and Stefanov, S., 2007. An intervention to enhance nursing staff teamwork and engagement. J Nurs Adm, 37(2): 77-84.

Kelly, B., 1992. The professional self-concepts of nursing undergraduates and their perceptions of influential forces. Journal of Nursing Education, 31(3): 121-125.

KemenkesRI, 2017. Situasi Tenaga Keperawatan, InfoDATIN. Kementrian Kesehatan RI, Jakarta.

Kemmer, L.F. and Silva, M.J.P.d., 2007. Nurses' Visibility According to The Perceptions of The Communication Professionals. Rev Latino-am Enfermagem, 15(1): 8.

Kim, M.S., 2011. Moderating Effects of Self-Esteem and Self-Efficacy in the Relationship between Professional Self-Concept and Satisfaction in their Major among Nursing Students. J Korean Acad Soc Nurs Edu, 17(2): 9.

Kovner, C., Brewer, C., Wu, Y.W., Cheng, Y. and Suzuki, M., 2006. Factors associated with work satisfaction of registered nurses. Journal of Nursing Scholarship, 38(1): 71-79.

Krugman, P., 1997. The Age of Diminished Expectations. U.S. Economic Policy in the 1990s. The MIT Press, Cambridge, Massachusetts, London, England, 240 pp.

Leathart, A.J., 1994. Communication and socialisation (2): perceptions of neophyte ITU nurses. Intensive and Critical Care Nursing, 10(2): 142-154.

Lee, H.K. and Yang, H.J., 2015. Influence of Professional Self-Concept and Professional Autonomy on Nursing Performance of Clinic Nurses. International Journal of Bio-Science and Bio-Technology, 7(5): 14.

Letvak, S. and Buck, R., 2008. Factors Influencing Work Productivity and Intent to Stay in Nursing. Nursing Economic\$, 26(3): 7. 
Mrayyan, M.T. and Al-Faouri, I., 2008. Predictors of career commitment and job performance of Jordanian nurses. Journal of Nursing Management, 16(3): 246-256.

Mudallal, R.H., Saleh, M.Y.N., Al-Modallal, H.M. and Abdel-Rahman, R.Y., 2017. Quality of nursing care: The influence of work conditions, nurse characteristics and burnout. International Journal of Africa Nursing Sciences, 7: 24-30.

Nam, K.-H. and Park, J.-H., 2002. A study on the relationship of empowerment with job satisfaction and organizational commitment perceived by nurses. Journal of Korean Academy of Nursing Administration, 8(1): 137-150.

Nursalam, 2016. Manajemen Keperawatan, Aplikasi dalam Praktek Keperawatan Profesional. Salemba Medika, Jakarta.

O'Mara, A.J., Marsh, H.W., Craven, R.G. and Debus, R.L., 2006. Do self-concept interventions make a difference? A synergistic blend of construct validation and meta-analysis. Educational Psychologist, 41(3): 181-206.

Randle, J., 2001. The effect of a 3-year preregistration training course on students' selfesteem. J Clin Nurs, 10(2): 293-300.

Roghanian, P., Rasli, A. and Gheysari, H., 2012. Productivity Through Effectiveness and Efficiency in the Banking Industry. Procedia Social and Behavioral Sciences, 40: 550-556.

Secrest, J.A., Norwood, B.R. and Keatley, V.M., 2003. "I was actually a nurse": The meaning of professionalism for baccalaureate nursing students. Journal of Nursing Education, 42(2): 77-82.

Takase, M., Kershaw, E. and Burt, L., 2002. Does public image of nurses matter? Journal of Professional Nursing, 18(4): 196-205.

Takase, M., Maude, P. and Manias, E., 2006. Impact of the perceived public image of nursing on nurses' work behaviour. Journal of Advanced Nursing, 53(3): 11.

ten Hoeve, Y., Jansen, G. and Roodbol, P., 2014. The nursing profession: public image, selfconcept and professional identity. A discussion paper. J Adv Nurs, 70(2): 295-309.

Tzeng, H.M., 2006. Testing a conceptual model of the image of nursing in Taiwan. Int J Nurs Stud, 43(6): 755-65.

Valizadeh, L. et al., 2016. Self-Esteem Challenges of Nursing Students: An Integrative Review. Research and Development in Medical Education, 5(1): 5-11.
Whitehead, J., 2001. Newly qualified staff nurses' perceptions of the role transition. British Journal of Nursing, 10(5): 330-339.

Williams, C.A., 2001. The RN shortage: not just nursing's problem. Academic Medicine, 76(3): 218-220.

Yaghoubi, M., Javadi, M., Rakhsh, F. and Bahadori, M., 2013. A study of determining factors affecting the performance of nurses based on the achieve model in selected hospital of Isfahan (Iran). J Educ Health Promot, 2: 49. 